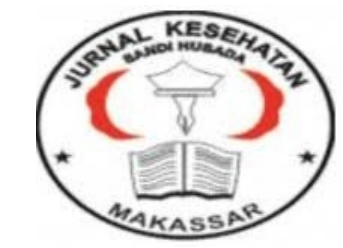

\author{
Jurnal Ilmiah Kesehatan Sandi Husada \\ hhttps://akper-sandikarsa.e-journal.id/JIKSH \\ Vol 11, No, 1, Juni 2020, pp;479-489 \\ p-ISSN: 2354-6093 dan e-ISSN: 2654-4563 \\ DOI: $10.35816 /$ jiskh.v10i2.331
}

\title{
Pengaruh Madu Ceiba Pentandra Terhadap Kadar LDL Tikus Rattus Norvegicus Yang Diberi Diet Tinggi Lemak
}

The effect of honey (Ceiba pentandra) to Low Density Lipid level of male rats (Rattus norvegicus) that has been given high fat diet

\author{
Hetti Rusmini' ${ }^{1}$, Devita Febriani ${ }^{2}$, Hidayat ${ }^{3}$, Dhani Risandy ${ }^{4}$ \\ ${ }^{1}$ Program Studi Kedokteran Fakultas Kedokteran Universitas Malahayati \\ 2 Departemen Parasitologi Fakultas Kedokteran Universitas Malahayati \\ ${ }^{3}$ Departemen Farmakologi Universitas Malahayati \\ ${ }^{4}$ Departemen Patologi Klinik Universitas Malahayati
}

\section{Artikel info \\ Artikel history:}

Received; Mei 2020

Revised: Juni 2020

Accepted; Juni2020

\begin{abstract}
.
Background: Hypercholesterolemia is a condition that body has increased cholesterol levels above normal threshold $(<200 \mathrm{mg} / \mathrm{dL}$ ). Hypercholesterolemia is the main risk factor for atherosclerosis which is the increase in Low Density Lipoprotein (LDL). Objectives: This study aims to determine the effect of Randu honey (Ceiba pentandra) on LDL levels of male rattus (Rattus norvegicus) strains given a high-fat-diet. Methodology: The type of research used is purely experimental using a pre-and-post test with group design. The population used in this study were 25 male Wistar strain rats which were divided into 5 groups. Sampling using the method of total sampling. Data were analyzed by Paired T-test and Anova. Research Results: From the 5 sample groups obtained the results of the analysis Paired T-Test, obtained a significant increase $(p<0.05)$ of LDL levels after giving a high-fat-diet in the negative group ( $p=$ $0.025)$, treatment group $2(p=0.001)$, and treatment group 3 ( $p=$ 0.001). In the treatment after the administration of honey, there was a significant decrease $(p<0.05)$ of LDL levels in 2 groups, namely in the treatment group $2(p=0.026)$, and the treatment group $3(p=$ 0.092). With Anova analysis, a significant difference was found in the treatment after the administration of a high-fat diet and after the provision of honey honey with the same $p$ value, namely $p=$ $0.001(P<0.05)$. Conclusion: There are differences that influence the administration of honey honey on LDL levels in wistar strain rats given a high-fat diet.
\end{abstract}

\begin{abstract}
Abstrak.
Latar Belakang: Hiperkolesterolemia adalah suatu kondisi tubuh yang mengalami peningkatan kadar kolesterol di atas ambang normal $(<200 \mathrm{mg} / \mathrm{dL})$. Hiperkolesterolemia merupakan faktor risiko utama terjadinya arterosklerosis dengan salah satunya adanya kenaikan Low Density Lipoprotein (LDL). Tujuan Penelitian: Penelitian ini bertujuan untuk mengetahui pengaruh pemberian madu
\end{abstract}


Randu (Ceiba pentandra) terhadap kadar LDL tikus (Rattus norvegicus) galur wistar jantan yang diberi diet tinggi lemak. Metode Penelitian: Jenis penelitian yang digunakan adalah eksperimental murni menggunakan rancangan penelitian pre and post test with group design. Populasi yang digunakan pada penelitian ini adalah 25 ekor tikus Galur Wistar jantan yang dibagi menjadi 5 kelompok. Pengambilan sampel menggunakan metode total sampling. Data dianalisa dengan uji Paired T-Test dan Anova. Hasil Penelitian: Pada penelitian ini, dari 5 kelompok sampel didapatkan hasil dengan analisa Paired T-Test, didapatkan peningkatan yang bermakna $(p<0,05)$ kadar LDL setelah pemberian diet tinggi lemak pada kelompok negatif $(p=0,025)$, kelompok perlakuan $2(p=$ $0,001)$, dan kelompok perlakuan $3(p=0,001)$. Pada perlakuan setelah pemberian madu randu, terdapat penurunan yang bermakna $(p<0,05)$ kadar LDL pada 2 kelompok yaitu pada kelompok perlakuan $2(p=0,026)$, dan kelompok perlakuan 3 $(p=0,092)$. Dengan analisa Anova, didapatkan perbedaan yang bermakna pada perlakuan setelah pemberian diet tinggi lemak dan setelah pemberian madu randu dengan nilai $p$ yang sama yaitu $p=0,001(P<0,05)$. Kesimpulan: Terdapat perbedaan yang berpengaruh pada pemberian madu randu terhadap kadar LDL pada tikus galur wistar yag diberi diet tinggi lemak

\author{
Keywords: \\ Hiperkolesterol; \\ Kadar LDL; \\ Madu Randu;
}

Corsponden author:

Email: dhanny.oon@gmail.com

artikel dengan akses terbuka dibawah lisensi BCC BY NC ND-4.0

\section{Pendahuluan}

Hiperkolesterolemia dapat terjadi karena gaya hidup (life style) yang tidak sehat, mulai dari pola makan yang tidak seimbang sampai kurangnya aktivitas olah raga. Pola makan tidak seimbang meliputi konsumsi makanan yang tinggi lemak dan karbohidrat, konsumsi makanan yang rendah serat, serta kebiasaan merokok dan juga minum alkohol. Kadar kolesterol yang tinggi di dalam tubuh dapat disebabkan oleh sintesis kolesterol dan penyerapan kolesterol yang tinggi dan juga karena konsumsi makanan yang tinggi lemak dan karbohidrat (Manalu et al., 2013). Hiperkolesterolemia adalah suatu kondisi tubuh yang mengalami peningkatan kadar kolesterol di atas ambang normal $(<200 \mathrm{mg} / \mathrm{dL})$. Hiperkolesterolemia ditandai dengan adanya kenaikan kadar kolesterol total, kolesterol Low Density Lipoprotein (LDL), dan penurunan High Density Lipoprotein (HDL) serta meningkatnya kadar trigliserida pada tubuh penderita. Hiperkolesterolemia merupakan kontributor utama pada penyakit jantung. Pada tahun 2005, 17,5 juta atau 30\% kematian di seluruh dunia disebabkan oleh penyakit jantung. Pada saat ini penyakit jantung merupakan penyebab kematian nomor satu di negara maju. World Health Organization (WHO) memprediksikan pada tahun 2020, penyakit jantung menjadi penyebab kematian nomor satu di dunia (Penelitian, 2014). 
Berdasarkan laporan WHO tahun 2002, tercatat sebanyak 4,4 juta kematian akibat hiperkolesterolemia atau sebesar 7,9\% dari jumlah total kemeatian di usia muda (Wignjosoesastro et al., 2014). Prevalensi hiperkolesterolemia di Negara Indonesia terus meningkat. Dalam kurun waktu 1988 dan 1993 survei Monitoring of Trends and Determinants in Cardiovascular Disease (MONICA) menunjukan bahwa prevalensi hiperkolesterolemia telah meningkat dari $13,6 \%$ menjadi $16,5 \%$ pada laki-laki dan $16 \%$ menjadi $17 \%$ pada perempuan (Penelitian, 2014). Berdasarkan (Dedullah et al., 2015) menggambarkan proporsi penduduk $>15$ tahun dengan kadar kolesterol total di atas nilai normal merujuk nilai yang ditentukan pada National Cholesterol Education Program Adult Treatment Panel III (NCEP-ATP III) adalah sebesar 35,9 persen, yang merupakan gabungan penduduk kategori borderline (nilai kolesterol total 200-239 mg/dl) dan tinggi (nilai kolesterol total $>240 \mathrm{mg} / \mathrm{dl}$ ).

Penilaian berdasarkan jenis kelamin dan tempat tinggal didapatkan bahwa proporsi penduduk dengan kadar kolesterol di atas normal pada perempuan lebih tinggi dibandingkan pada laki-laki, dan di daerah perkotaan lebih tinggi dibandingkan daerah perdesaan. Hiperkolesterolemia merupakan faktor risiko utama terjadinya arterosklerosis dan mampu menimbulkan lesi tersebut tanpa adanya faktor risiko yang lain. Komponen kolesterol utama yang berkaitan dengan meningkatnya risiko adalah kolesterol LDL. LDL menditribusikan kolesterol ke jaringan perifer dan sebaliknya, HDL memobilisasi kolesterol dari plak pembuluh darah yang sedang terbentuk maupun yang telah ada di hati untuk diekskresikan bersama bilirubin, maka jika kadar HDL yang tinggi akan menurunkan risiko arterosklerosis (Cheng et al., 2018).

Kolesterol merupakan sterol utama dalam tubuh manusia dan komponen struktural membran sel dan lipoprotein plasma, serta sebagai bahan awal pembentukan asam empedu dan hormon steroid. Sterol dan derivatifnya sukar larut dalam larutan berair tetapi larut dalam pelarut organik terutama alkohol, sehingga senyawa ini dimasukkan dalam golongan lipid . Lovastatin merupakan obat golongan statin yang digunakan untuk menurunkan kadar kolesterol dalam darah. Lovastatin menghambat HMG-CoA reduktase, enzim yang berperan dalam biosintesis kolesterol Berdasarkan studi Pan Asian yang disebut Centralised Pan-Asian Survey on the under treatment of hypercholesterolemia (CEPHEUS), 68,7\% pasien hiperkolesterolemia di Indonesia gagal mencapai target terapi. Hal ini dikarenakan rendahnya tingkat ekonomi dan pendidikan masyarakat Indonesia. Hampir setengah dari mereka yang menjalankan terapi kerap lupa mengonsumsi satu dosis obat dalam jangka waktu satu minggu atau lebih, bahkan sebanyak 65,1\% pasien mengaku lupa mengonsumsi obat penurun kadar kolesterol beberapa kali dan menganggap hal tersebut tidak memengaruhi kadar kolesterol mereka (Penelitian, 2014). Al-Waili (2004) melaporkan di Dubai bahwa konsentrasi kolesterol total dapat turun dengan pemberian madu sebesar 75 gr setiap hari. Penelitian Perez et al (2006) menunjukan bahwa madu dapat menurunkan lipid peroksida dan malonaldealdehida atau sering disingkat MDA. Mekanisme terjadinya penurunan kolesterol dan MDA pada pemberian madu tersebut diduga karena adanya aktivitas antioksidan yang terkandung di dalam madu.

Menurut Standar Nasional Indonesia (SNI) 3545:2013, definisi madu adalah cairan alami yang umumnya mempunyai rasa manis yang dihasilkan oleh lebah madu (Apis sp.) dari sari bunga tanaman (flora nektar) atau bagian lain dari tanaman. Madu adalah zat manis yang dihasilkan oleh lebah madu, yang berasal dari nectar bunga atau dari sekresi tanaman yang dikumpulkan oleh lebah. Kandungan mineral pada madu mempengaruhi 
warna pada madu. Kandungan mineral ini dapat berasal dari tanah tempat tumbuh tanaman dan juga pengaruh kontaminan cemaran (Gallmann, 2007). Kandungan antioksidan pada madu terdiri dari antioksidan enzimatis dan non enzimatis. Antioksidan enzimatis pada madu yaitu katalase, glukosa oksidase, dan peroksidase, sedangkan antioksidan non enzimatis yaitu asam askorbat, flavonoid, asam amino, dan protein (Gallmann, 2007) Penelitian ini bertujuan untuk mengetahui pengaruh pemberian madu Randu (Ceiba pentandra) terhadap kadar LDL tikus (Rattus norvegicus) galur wistar jantan yang diberi diet tinggi lemak.

\section{Metode}

Penelitian dilakukan di Laboratorium Biologi Medik Universitas Malahayti Bandar Lampung untuk pemeliharaan dan perlakuan sampel, serta Apotik Rosa Bandar Lampung untuk pemeriksaan kadar LDL (Low Density Lipid). Penelitian ini menggunakan 25 sampel tikus jenis Galur Wistar jantan. Penelitian ini merupakan penelitian eksperimental murni dengan rancangan penelitian pre and post test with group design. Sampel yang digunakan dibagi menjadi 5 kelompok yang dipilih secara acak. Masing masing kelompok diberikan perlakuan berbeda yaitu sebagai kelompok kontrol, kelompok negatif, kelompok perlakuan 1, perlakuan 2 dan perlakuan 3. Pengambilan kadar LDL pada tikus dilakukan sebanyak 3 kali yaitu sebelum pemberian diet tinggi lemak, setelah pemberian diet tinggi lemak serta setelah pemberian madu randu. Data hasil penelitian kemudian dianalisa menggunakan program SPSS untuk mengetahui distribusi frekuensi masing masing data serta mengetahui perngaruh madu randu terhadap kadar LDL pada tikus Galur Wistar jantan.

Cara pengambilan darah pada tikus: tikus dipuasakam -+ 12 jam sebelum pengambilan darah. Pengambilan darah dilakukan sebanyak 2 kali, yaitu sebelum perlakuan dan setelah perlakuan. Pengambilan darah dilakukan dengan cara tikus dianestesi terlebih dahulu menggunakan eter lalu dipegang dan dijepit bagian tengkuk dengan jari tangan. Tikus dikondisikam senyaman mungkin, kemudian pipa kapiler digoreskan pada retro-orbital pleksus. Pipa kapiler diputar sampai melukai pleksus, lalu darah ditampung pada tube EDTA untuk tujuan pengambilan plasma darah. Darah yang diambil dari setiap mata tikus berkisar antara 1-1,5 ml. Darah didiamkan selama 15 menit dengan kecepatan $3000 \mathrm{rpm}$. Plasma darah yang diperoleh dipipet menggunakan pipet mikro dan dimasukan kedalam tabung effendorf lalu disimpan pada suhu -20 derajat celcius. Kadar LDL normal pada tikus dalam darah adalah 7-27,2 $\mathrm{mg} / \mathrm{dl}$, untuk mengetahui kadar LDL pada awal perlakuan. Dikatakan tinggi ketika kadar LDL mencapai $>27,2 \mathrm{mg} / \mathrm{dl}$. 


\section{Hasil Dan Pembahasan}

Tabel 1 Distribusi frekuensi kadar LDL sebelum dan setelah pemberian diet tinggi lemak serta setelah pemberian Madu Randu

\begin{tabular}{|c|c|c|c|c|c|}
\hline \multirow{3}{*}{ Kelompok } & \multirow[b]{2}{*}{$\begin{array}{l}\text { Sebelum diet } \\
\text { tinggi lemak }\end{array}$} & \multirow[b]{2}{*}{$\begin{array}{c}\text { Setelah diet } \\
\text { tinggi } \\
\text { lemak }\end{array}$} & \multirow[b]{2}{*}{$\begin{array}{c}\text { Setelah } \\
\text { pemberian } \\
\text { madu randu }\end{array}$} & \multicolumn{2}{|c|}{ Presentase perubahan } \\
\hline & & & & $\begin{array}{l}\text { Setelah } \\
\text { diet tinggi } \\
\text { lemak }\end{array}$ & $\begin{array}{c}\text { Setelah } \\
\text { pemberian } \\
\text { madu } \\
\text { randu }\end{array}$ \\
\hline & Rata rata \pm SD & & & $\%$ & \\
\hline KK & $20,2 \pm 3,96$ & $20,4 \pm 4,03$ & $20,8 \pm 3,76$ & 0,99 & 1,96 \\
\hline KN & $20,0 \pm 1,09$ & $29,6 \pm 5,22$ & $31,2 \pm 3,27$ & 48 & 5,4 \\
\hline $\mathrm{P} 1$ & $20,4 \pm 4,27$ & $30,0 \pm 4,69$ & $27,8 \pm 2,28$ & 47 & $-7,33$ \\
\hline P2 & $18,8 \pm 3,89$ & $31,2 \pm 2,58$ & $27,8 \pm 1,64$ & 65,9 & $-10,9$ \\
\hline P3 & $20,20 \pm 2,04$ & $32,6 \pm 2,07$ & $29,0 \pm 3,16$ & 61,3 & $-11,04$ \\
\hline
\end{tabular}

Sumber: Data Primer, 2019

Tabel 2 Rerata kadar LDL sebelum pemberian diet tinggi lemak dan setelah pemberian diet tinggi lemak

\begin{tabular}{cccc}
\hline \multirow{2}{*}{ Kelompok } & $\begin{array}{c}\text { Sebelum diet tinggi } \\
\text { lemak }\end{array}$ & $\begin{array}{c}\text { Setelah diet tinggi } \\
\text { lemak }\end{array}$ & \multirow{2}{*}{$\begin{array}{c}\text { Nilai } \mathrm{p} \text { uji } \\
\text { Paired T-Test }\end{array}$} \\
\cline { 2 - 3 } KK & \multicolumn{2}{c}{ Rata rata \pm SD } & 0,876 \\
\hline KN & $20,2 \pm 3,96$ & $20,4 \pm 4,03$ & 0,025 \\
\hline P1 & $20,0 \pm 1,09$ & $29,6 \pm 5,22$ & 0,046 \\
\hline P2 & $20,4 \pm 4,27$ & $30,0 \pm 4,69$ & 0,001 \\
\hline P3 & $18,8 \pm 3,89$ & $31,2 \pm 2,58$ & 0,001 \\
\hline
\end{tabular}

Sumber: Data Primer, 2019

Tabel 3 Rerata kadar LDL setelah pemberian diet tinggi lemak dan setelah pemberian madu Randu

\begin{tabular}{|c|c|c|c|}
\hline \multirow{2}{*}{ Kelompok } & $\begin{array}{l}\text { Setelah diet tinggi } \\
\text { lemak }\end{array}$ & $\begin{array}{l}\text { Setelah pemberian madu } \\
\text { randu }\end{array}$ & \multirow{2}{*}{$\begin{array}{l}\text { Nilai } p \text { hasil uji } \\
\text { Paired T-test }\end{array}$} \\
\hline & \multicolumn{2}{|c|}{ Rata rata \pm SD } & \\
\hline KK & $20,4 \pm 4,03$ & $20,8 \pm 3,76$ & 0,816 \\
\hline $\mathrm{KN}$ & $29,6 \pm 5,22$ & $31,2 \pm 3,27$ & 0,444 \\
\hline $\mathrm{P} 1$ & $30,0 \pm 4,69$ & $27,8 \pm 2,28$ & 0,307 \\
\hline $\mathrm{P} 2$ & $31,2 \pm 2,58$ & $27,8 \pm 1,64$ & 0,026 \\
\hline $\mathrm{P}_{3}$ & $32,6 \pm 2,07$ & $29,0 \pm 3,16$ & 0,092 \\
\hline
\end{tabular}

Sumber: Data Primer, 2019 


\section{Pembahasan}

\section{Perbedaan kadar LDL sebelum dan sesudah pemberian diet tinggi lemak}

Berdasarkan hasil penelitian pada tabel 1, rerata kadar LDL sebelum dan sesudah pemberian diet tinggi lemak mengalami perubahan. Perubahan tersebut terjadi pada semua kelompok, namun tidak semua perubahan rerata kadar LDL tersebut bermakna $(\mathrm{p}<0,05)$. Pada kelompok kontrol, kadar LDL terlihat mengalami perubahan. Sebagai kelompok kontrol, kelompok ini tidak menerima diet tinggi lemak. Namun berdasarkan hasil penelitian, didapatkan peningkatan rerata kadar LDL pada kelompok tersebut. Rata rata kadar LDL pada kelompok kontrol sebelum pemberian diet tiggi lemak adalah 20,2 $\mathrm{mg} / \mathrm{dl}$ dan setelah pemberian diet tinggi lemak, rata rata kadar LDL kelompok kontrol adalah 20,4 mg/dl. Kadar LDL pada kelompok kontrol hanya meningkat 0,2 mg/dl. Sementara itu hasil uji Paired T-test yang dilakukan pada kelompok ini menunjukan nilai $p=0,876(p>0,05)$ yang berarti walaupun ada perubahan berupa peningkatan rerata kadar LDL, perubahan ini tidak bermakna dikarenakan hasil analisa statistik menunjukan nilai $p>0,05$. Peningkatan ini terjadi karena berbagai macam faktor seperti lingkungan dan lainnya, namun peningkatan ini terjadi tidak terlalu besar jika dibandingkan dengan kelompok lainnya.

Pada perlakuan kelompok negatif, didapat peningkatan yang pesat jika dibandingkan dengan kelompok kontrol. Rerata kadar LDL pada kelompok negatif sebelum pemberian diet tinggi lemak adalah 20,0 mg/dl, dan langsung melonjak menjadi 29,60 mg/dl setelah diberikan diet tinggi lemak. Perubahan rerata kadar LDL pada kelompok negatif ini sebanyak 9,6 mg/dl atau meningkat sebesar 48\%. Berdasarkan hasil uji Paired T-test yang dilakukan, didapatkan hasil dengan nilai $p=0,025$. Hasil ini membuktikan bahwa pada kelompok negatif memiliki perbedaan yang bermakna $(p<0,05)$ antara sebelum pemberian diet tinggi lemak dan setelah pemberian diet tinggi lemak. Pada kelompok perlakuan 1 (P1), kelompok perlakuan 2 (P2) dan kelompok perlakuan 3 (P3), terjadi peningkatan rerata kadar LDL pada sampel penelitian. Berdasarakan hasil penelitian ini, rata rata kadar LDL pada kelompok perlakuan 1 (P1) sebelum diberikan diet tinggi lemak sebesar 20,4 mg/dl, angka ini meningkat menjadi 30,0 mg/dl setelah diberikan diet tinggi lemak. Rerata kadar LDL pada kelompok ini meningkat sebanyak 9,6 mg/dl atau 47\%. Berdasarkan uji Paired T-test pada kelompok ini, didapatkan nilai $\mathrm{p}=0,046$. Hasil ini membuktikan bahwa pada kelompok perlakuan 1 (P1) terdapat perbedaan yang bermakna $(p<0,05)$ antara sebelum pemberian diet tinggi lemak dan setelah pemberian diet tinggi lemak.

Pada kelompok perlakuan 2 (P2), hasil penelitian juga menunjukan terjadinya peningkatan rerata kadar LDL pada sampel penelitian. Berdasarkan hasil penelitian, kadar LDL sebelum pemberian diet tinggi lemak pada kelompok ini sebesar 18,8 mg/dl dan meningkat menjadi $31,2 \mathrm{mg} / \mathrm{dl}$ setelah pemberian diet tinggi lemak. Rerata kadar LDL pada kelompok ini meningkat sebanyak $12,4 \mathrm{mg} / \mathrm{dl}$ atau 65,9\%. Berdasarkan uji Paired Ttest pada kelompok ini, didapatkan nilai $\mathrm{p}=0,001$. Hasil ini membuktikan bahwa pada kelompok perlakuan 2 (P2) terdapat perbedaan yang sangat bermakna $(\mathrm{p}<0,05)$ antara sebelum pemberian diet tinggi lemak dan setelah pemberian diet tinggi lemak. Pada kelompok perlakuan 3, hasil yang sama juga diperlihatkan pada kelompok ini, yaitu terjadinya peningkatan kadar LDL setelah pemberian diet tinggi lemak. Rerata kadar LDL sebelum perlakuan pada kelompok ini adalah $20,2 \mathrm{mg} / \mathrm{dl}$ dan menjadi $32,6 \mathrm{mg} / \mathrm{dl}$ setelah diberikan diet tinggi lemak. Rerata kadar LDL pada kelompok ini meningkat sebanyak 16,4 
$\mathrm{mg} / \mathrm{dl}$ atau 61,3\%. Berdasarkan uji Paired T-test pada kelompok ini, didapatkan nilai $\mathrm{p}=0,001$. Hasil ini serupa dengan perlakuan pada kelompok 2 (P2) yang membuktikan bahwa pada kelompok perlakuan 3 (P3) ini terdapat perbedaan yang sangat bermakna $(p<0,05)$ antara sebelum pemberian diet tinggi lemak dan setelah pemberian diet tinggi lemak.

Hasil penelitian ini sesuai dengan teori yang mengatakan bahwa pemberian diet tinggi lemak dapat menimbulkan stress oksidatif endotel pembuluh darah melalui pembentukan keadaan dyslipidemia yaitu tingginya kadar kolestrol total, LDL,VLDL, TG dan rendahnya kadar HDL dalam sirkulasi. Stress oksidatif dapat menyebabkan disfungsi endotel dan produksi berlebihan dari ROS (Reactive Oxygen Species) yang akan mengoksidasi LDL ekstraseluler sehingga terbentuklah LDL teroksidasi. LDL teroksidasi akan difagositosis oleh makrofag melalui reseptor scavenger sehingga terbentuk sel busa sebagai lesi awal aterosklerosis (Welinsa et al., 2014). Pemberian diet tinggi lemak pada sampel penelitian terbukti dapat meningkatkan kadar LDL. Hasil penelitian ini juga sesuai dengan hasil penelitian oleh (Tsalissavrina et al., 2006) , pada pemberian diet tinggi lemak selama 12 minggu dapat menaikan kadar trigliserida dengan perbedaan yang signifikan (Tsalissavrina et al., 2006).

\section{Perbedaan kadar LDL setelah pemberian diet tinggi lemak dan setelah pemberian madu randu}

Berdasarkan tabel 3 pada penelitian ini, terdapat beberapa perubahan kadar LDL. Terdapat peningkatan dan penurunan rerata kadar LDL setelah perlakuan pemberian madu randu pada penelitian ini, namun tidak semua perubahan tersebut bermakna. Dengan analisa uji Paired T-test, hanya terdapat satu kelompok perlakuan yang memiliki perbedaan yang bermakna. Pada kelompok kontrol, kadar LDL terlihat mengalami perubahan. Sebagai kelompok kontrol, kelompok ini tidak menerima diet tinggi lemak ataupun asupan madu randu. Namun, berdasarkan hasil penelitian, didapatkan peningkatan rerata kadar LDL pada kelompok tersebut. Terlihat pada tabel 3, rerata kadar LDL pada kelompok kontrol semakin meningkat. Pada perlakuan sebelumnya, kelompok ini memiliki rerata kadar LDL sebanyak $20,4 \mathrm{mg} / \mathrm{dl}$ dan meningkat menjadi 20,8. Rerata kadar LDL pada kelompok ini meningkat sebanyak 0,4 mg/dl atau 0,19\%. Berdasarkan uji Paired T-test pada kelompok ini, didapatkan nilai $p=0,816 \quad(p>0,05)$. Hasil ini membuktikan bahwa pada kelompok kontrol tidak terdapat perbedaan yang bermakna $(\mathrm{p}<0,05)$ antara setelah pemberian diet tinggi lemak dan setelah perlakuan pemberian madu randu.

Kelompok negatif merupakan kelompok yang hanya diberikan diet tinggi lemak tanpa diberikan perlakuan pemberian madu randu, hal ini dilakukan agar peneliti dapat mengetahui kadar LDL setelah pemberian madu randu tanpa harus diberikan madu randu. Hasil penelitian menunjukan bahwa rerata kadar LDL pada kelompok negatif cenderung semakin meningkat. Rerata kadar LDL pada kelompok ini setelah diberikan diet tinggi lemak adalah 29,6 mg/dl dan meningkat menjadi 31,2 mg/dl setelah perlakuan pemberian madu randu. Kelompok ini mengalami perubahan peningkatan rerata kadar LDL sebanyak $1,6 \mathrm{mg} / \mathrm{dl}$ atau 5,4\%. Hal ini juga membuktikan bahwa sampel penelitian yang diberikan diet standard dan diet tinggi lemak akan mengalami peningkatan kadar LDL. Berdasarkan uji Paired T-test pada kelompok ini, didapatkan nilai $p=0,444 \quad(p>0,05)$. Hasil ini membuktikan bahwa pada kelompok negatif juga tidak terdapat perbedaan yang bermakna $(\mathrm{p}<0,05)$ antara setelah pemberian diet tinggi lemak dan setelah perlakuan pemberian madu randu. 
Pada kelompok perlakuan 1 (P1), kelompok perlakuan 2 (P2) dan kelompok perlakuan 3 (P3), terjadi penurunan rerata kadar LDL pada sampel penelitian. Pada kelompok perlakuan 1, sampel penelitian diberikan diet tinggi lemak lalu kemudian di intervensi dengan pemberian madu randu dengan dosis $0,25 \mathrm{ml} / 200$ gramBB. Hasil penelitian ini, rata rata kadar LDL pada kelompok perlakuan 1 ini meningkat menjadi 30,0 mg/dl setelah diberikan diet tinggi lemak, namun angka tersebut menurun menjadi $27,8 \mathrm{mg} / \mathrm{dl}$ yang berarti madu randu pada dosis tersebut mampu menurunkan sekitar 2,2 $\mathrm{mg} / \mathrm{dl}$ atau 7,3\% kadar LDL pada sampel penelitian. Berdasarkan uji Paired T-test pada kelompok ini, didapatkan nilai $p=0,307(p>0,05)$. Hasil ini membuktikan bahwa pada kelompok perlakuan $1(P 1)$ juga tidak terdapat perbedaan yang bermakna $(p<0,05)$ antara setelah pemberian diet tinggi lemak dan setelah perlakuan pemberian madu randu.

Pada kelompok perlakuan 2, hasil penelitian juga menunjukan terjadinya penurunan rerata kadar LDL pada sampel penelitian. Pada kelompok ini peneliti menggunakan dosis madu sebesar 0,5 ml/200gramBB. Berdasarkan hasil penelitian, kadar LDL meningkat menjadi $31,2 \mathrm{mg} / \mathrm{dl}$ setelah pemberian diet tinggi lemak, namun angka ini mengalami penurunan ketika sampel diberikan madu randu. Rerata kadar LDL pada kelompok ini menjadi 27,8 mg/dl. Rerata kadar LDL pada kelompok ini menurun sebesar 3,4 mg/dl atau 10,9\%. Berdasarkan uji Paired T-test pada kelompok ini, didapatkan nilai $\mathrm{p}=0,026$ $(\mathrm{p}<0,05)$. Hasil ini membuktikan bahwa pada kelompok perlakuan 2 (P2) memiliki perbedaan yang bermakna $(\mathrm{p}<0,05)$ antara setelah pemberian diet tinggi lemak dan setelah perlakuan pemberian madu randu.

Pada kelompok perlakuan 3, hasil yang sama juga diperlihatkan pada kelompok ini, yaitu terjadi penurunan kadar LDL. Rerata kadar LDL setelah diberikan diet tinggi lemak pada kelompok ini adalah 32,6 mg/dl. Angka ini menurun menjadi 29,0 mg/dl setelah kelompok perlakuan 3 mendapatkan asupan madu randu dengan dosis 0,75 ml/200gramBB. Kelompok perlakuan ini mengalami penurunan rerata kadar LDL sebanyak 3,6 mg/dl atau sebesar $11,0 \%$ setelah diberikan madu randu. Berdasarkan uji Paired T-test pada kelompok ini, didapatkan nilai $\mathrm{p}=0,096(\mathrm{p}>0,05)$. Hasil ini membuktikan bahwa pada kelompok perlakuan 3 (P3) juga tidak memiliki perbedaan yang bermakna $(p<0,05)$ antara setelah pemberian diet tinggi lemak dan setelah perlakuan pemberian madu randu. Berdasarkan hasil penelitian ini, dapat dibuktikan bahwa hanya kelompok perlakuan 2 (P2) yang memiliki perubahan bermakna setelah sampel penelitian menerima asupan madu randu dengan dosis 0,5 ml/200gramBB.

Sampel penelitian yang diberikan madu randu dengan berbagai dosis, terbukti dapat menurunkan kadar LDL sekitar 7,3-11\% dari kadar LDL sebelum pemberian madu. Hal ini sesuai dengan teori yang mengatakan bahwa vitamin B3 atau niasin juga yang terdapat dalam madu sangat berperan dalam metabolisme lemak. Niasin berperan dalam menurunkan kadar trigliserida dan apolipoprotein- $\beta$ dengan cara mengurangi perpindahan asam lemak dari jaringan adiposa (lipolisis), menghambat diacylglycerol acyltransferase (DGAT) yang merupakan enzim untuk sintesis trigliserida (Ekananda, 2015). Hal ini dapat terjadi karena madu dapat menurunkan lipid peroksida malonaldealdehida atau sering disingkat MDA. Mekanisme terjadinya penurunan kadar kolesterol dan MDA pada pemberian madu tersebut diduga karena adanya aktivitas antioksidan yang terkandung di dalam madu. Hasil penelitian ini sesuai dengan penelitian oleh Sitti Rahma, dkk yaitu berdasarkan hasil pemeriksaan kolesterol dapat dilihat bahwa madu dorsata dan madu trigona mampu menurunkan kadar kolesterol (nilai $\mathrm{p}<0,013$ ). 
Madu digunakan sebagai penurun kolesterol karena didalam madu terkandung vitamin C (Rahma et al., 2014).

\section{Analisa pengaruh pemberian madu randu terhadap kadar LDL}

Berdasarkan hasil penelitian ini terdapat pengaruh pemberian diet tinggi lemak dan pemberian madu randu. Hasil ini didapatkan dari uji Paired T-test yang dilakukan peneliti untuk mencari adanya perbedaan yang paling bermakna $(p<0,05)$ dari berbagai macam kelompok di setiap perlakuan. Berdasarkan tabel 2 didapatkan kelompok kontrol nilai $p=0,876(p>0,05)$ yang berarti tidak terdapat perbedaan yang bermakna antara rerata kadar LDL sebelum dan sesudah pemberian diet tinggi lemak. Hal ini terjadi dikarekan kelompok kontrol hanya dijadikan sebagai patokan, sehingga tidak mendapat perlakuan pemberian diet tinggi lemak ataupun pemberian madu. Maka dari itu hasil dari kelompok kontrol mengalami perubahan namun tidak bermakna.

Pada kelompok negatif, didapatkan nilai $p=0,025(p<0,05)$ yang berarti terdapat perbedaan yang bermakna antara rerata kadar LDL sebelum dan sesudah pemberian diet tingi lemak. Hal ini dapat terjadi dikarenakan perubahan rerata kadar LDL yang sangat drastis jika dibandingkan dengan kelompok kontrol, hal ini juga terjadi pada kelompok perlakuan 1, 2 dan 3. Kelompok perlakuan 1 mempunyai nilai $p=0,046(p<0,05)$ yang berarti kelompok perlakuan 1 juga memiliki perbedaan yang bermakna. Pada kelompok perlakuan 2 dan 3, hasil yang didapatkan menunjukan angka yang sama yaitu nilai $p=0,01$ $(\mathrm{p}<0,05)$. Hal ini menunukan kedua kelompok ini memiliki perbedaan yang sangat bermakna jka dibandingkan kelompok kelompok lainnya. Hasil ini sesuai dengan teori yang menggambarkan bahwa konsumsi diet tinggi lemak dapat memacu peningkatan kadar LDL pada sampel.

Hal ini terjadi dikarenakan konsumsi diet tinggi lemak akan meningkatkan kadar kolesterol tubuh. Sel-sel menyerap kolesterol dari darah dengan menyintetis protein reseptor yang secara spesifik mampu mengikat LDL dan menyisipkan reseptor-reseptor ini ke membran plasma. Penelitian ini juga mendapatkan hasil analisa perbedaan yang bermakna pada perlakuan setelah pemberian madu randu dimasing masing kelompok. Pada tabel 3 dapat dilihat rerata kadar LDL pada sampel penelitian. Berdasarkan tabel tersebut, kelompok kontrol memiliki nilai $p=0,816(p>0,05)$ yang berarti kelompok ini tidak memiliki perbedaan yang bermakna setelah pemberian madu randu. Hal ini terjadi karena sebagai kelompok kontrol, peneliti hanya menempatkan kelompok ini sebagai patokan terhadap kelompok lainnya, yaitu dengan tidak memberikan madu randu sehingga perbedaan yang didapatkan tidak bermakna.

Pada kelompok negatif, peneliti juga tidak memberikan perlakuan pemberian madu randu. Hal ini dikarenakan peneliti menggunakan kelompok negatif sebagai indicator untuk melihat rerata LDL tanpa harus memberikan madu randu, sehingga hasil analisa yang didapatkan terdapat peningkatan kadar LDL namun perbedaan tersebut tidak bermakna dengan nilai $\mathrm{p}=0,444(\mathrm{p}>0,05)$. Pada kelompok perlakuan 1 , hasil yang didapatkan adalah nilai $p$ sebesar $0,307(p>0,05)$ yang berarti walaupun terdapat penurunan rerata kadar LDL, perubahan yang terjadi tidak bermakna. Hasil ini berbeda dengan kelompok perlakuan 2 pada kelompok perlakuan 2 adalah kelompok dengan perbedaan yang bermakna dengan nilai $\mathrm{p}=0,026$ yang berarti kelompok perlakuan 2 adalah kelompok yang berpengaruh menurunkan rerata kadar LDL pada sampel penelitian. Pada kelompok perlakuan 3, hasil yang sama didapatkan seperti pada kelompok perlakuan 1 . Hasil yang 
didapatkan pada kelompok ini sebesar $\mathrm{p}=0,092(\mathrm{p}<0,05)$ yang berarti pada kelompok ini tidak memiliki perbedaan yang bermakna.

Dari ketiga kelompok perlakuan ini, walaupun perlakuan 2 merupakan kelompok yang memiliki perbedaan yang bermakna, namun berdasarkan uji Post Hoc Bonferonni menunjukan tidak ada pengaruh bermakna pada ketiga kelompok perlakuan terhadap penurunan kadar LDL pada sampel. Hasil ini berbeda dengan teori dimana madu digunakan sebagai penurun kolesterol karena didalam madu terkandung vitamin C. Vitamin C merupakan salah satu antioksidan yang berperan dalam menurunkan kolesterol. Hal tersebut dikarenakan vitamin $\mathrm{C}$ dapat menghambat penyerapan kolesterol yang berlebih di dalam darah. Vitamin C mampu meningkatkan pengubahan kolesterol menjadi bentuk senyawa lain seperti asam empedu dan garam empedu (Waspadji (2003) dan Suhartono 2003).

\section{Simpulan Dan Saran}

Berdasarkan hasil penelitian ini, pemberian madu randu terhadap kadar LDL pada tikus Galur Wistar (Rattus norvegicus) jantan yang diberikan diet tinggi lemak dapat disimpulkan bahwa terbukti pemberian madu randu (Ceiba pentandra) dapat menurunkan kadar LDL tikus (Rattus norvegicu)sgalur wistar jantan. Hasil penelitian ini juga dapat digunakan sebagai referensi bagi peneliti selanjutnya. Untuk penelitian selanjutnya perlu dilakukan penelitian yang lebih lama untuk menilai pengaruh madu randu terhadap kadar LDL pada tikus Galur Wistar (Rattus norvegicus) jantan yang diberikan diet tinggi lemak dan dilakukan penelitian manfaat madu randu terhadap penyakit lain serta diharapkan dapat membantu masyarakat untuk lebih paham dan menggunakan madu randu sebagai salah satu cara untuk menurunkan kadar LDL dalam darah, sehingga menurunkan kadar kolesterol yang buruk bagi kesehatan..

\section{Daftar Rujukan}

Munstedt, K., Hoffman, S, Hauenschild., Bulte, M., Georgi, V.R., Hackethal, A. (2009). Effect of Honey On Serum Cholesterol and Lipid Values. J Med Food 12 (3): 624-628.

Musunuru, K. (2010). Atherogenic dyslipidemia: cardiovascular risk dietary intervention. Lipids, 45(10), 907-14.

Cheng, C. P., Wu, K. L., Mai, C. C., Yang, C. T. C. K. C. T., Hsu, Y. S., Yan, B. H. B. H., Wüthrich, R., Abou Ziki, J. D., Paul, L., Korah, L. V., Sarkar, B. R., Doloi, B. N., Bhattacharyya, B.,

Zhang, Z., Huang, L., Jiang, Y. Y., Liu, G., Nie, X., Lu, H., ... Little, A. D. (2018). No Title. International Journal of Machine Tools and Manufacture, 5(1), 86-96. https://doi.org/10.1016/j.ijmachtools.2009.09.004

Dedullah, R. F., Malonda, N. S. H., \& Joseph, W. B. S. (2015). Hubungan antara faktor risiko hipertensi dengan kejadian hipertensi pada masyarakat di Kelurahan Motoboi Kecil Kecamatan Kotamobagu Selatan Kota Kotamobagu. Jurnal Kesmas, 4(2), 111118.

Ekananda, N. A. (2015). [Artikel Review] Bay Leaf in Dyslipidemia Therapy. Dyslipidemia Therapy J MAJORITY|, 4, 64.

Gallmann, P. (2007). Minerals in honey: environmental, geographical and botanical aspects. Journal of Apicultural Research, August 2016, 269-275. https://doi.org/10.3896/ibra.1.46.4.11

Manalu, W., Suprayogi, A., Astuti, D. A., Anatomi, D., Hewan, F. K., Pertanian, I., Biologi, P. S., Pendidikan, F., Pengetahuan, I., Indonesia, U. P., Ilmu, D., Ternak, P., \& Peternakan, F. (2013). Perbaikan Parameter Lipid Darah Mencit Hiperkolesterolemia dengan 
Suplemen Pangan Bekatul Improvement of Blood Lipid Parameters of Hypercholesterolemic Mice by Supplementation of Rice Bran. 45(1), 1-9.

Penelitian, A. (2014). Artikel Penelitian Pengaruh Bawang Putih (Allium Sativum) Terhadap Pencegahan Hiperkolesterolemia Pada Tikus The Effect Of Garlic (Allium Sativum ) On Prevention Of. 13(1), 9-16.

Rahma, S., Natsir, R., Kabo, P., Keperawatan, I., Gorontalo, U. N., Biokimia, B., Kedokteran, F., Hasanuddin, U., Kardiologi, B., Kedokteran, F., Hasanuddin, U., Dorsata, M., \& Trigona, M. (2014). 1, 2 , 3. 4(4), 377-384.

Tsalissavrina, I., Wahono, D., \& Handayani, D. (2006). With High-Fat Diet Toward Triglyceride and Hdl Level in Blood. Pengaruh Pemberian Diet Tinggi Karbohidrat Dibandingkan Diet Tinggi Lemak Terhadap Kadar Trigliserida Dan Hdl

Darah Pada Rattus Novergicus Galur Wistar, 22(2), 80-89. https://jkb.ub.ac.id/index.php/jkb/article/viewFile/229/220

Welinsa, F., Asni, E., Malik, Z., \& Ismawati. (2014). Histopatologi Aorta Torasika Rattus Novergicus Strain Wistar Jantan Setelah 8 Minggu Pemberian Diet Aterogenik. Jom FK, 2(1), 1-11. https://doi.org/10.1017/CB09781107415324.004 